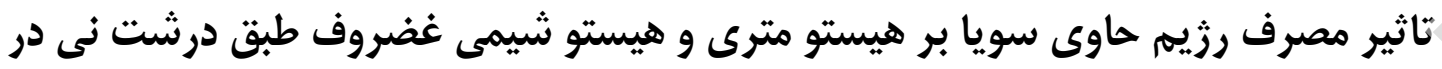 موش هاى NMRI ماده يس از القاى استئو آرتريت
}

ريحانه هوشمنل عباسى '، زهرا طوطيان '، حسن مروتى '، سيمين فاضلى يور '، بهادر شجاعى '، على كاظميان '

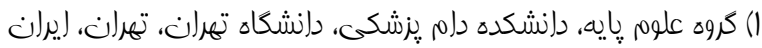

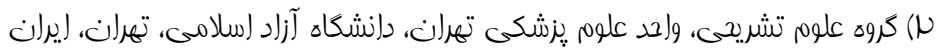

راه

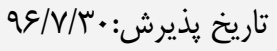

تاريخ دريافت:

جكيده

مقدمه: استئو آرتريت رايج ترين بيمارى مفصل زانو در افراد ميان سال است كه موجب محدود شدن حركت مى شود. هدف از انجام اين

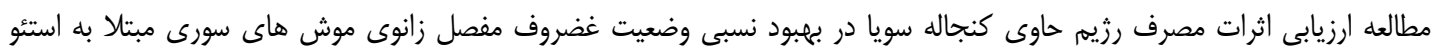
آرتريت مىباشد.

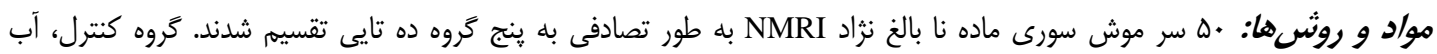

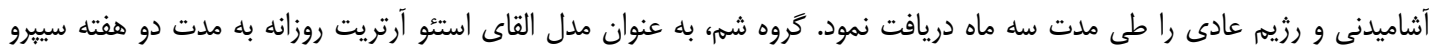

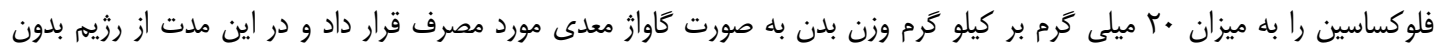

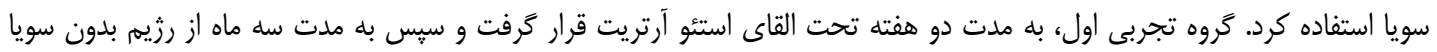

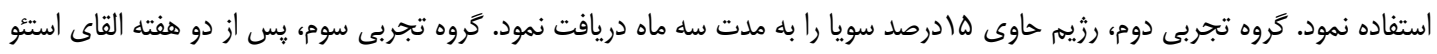

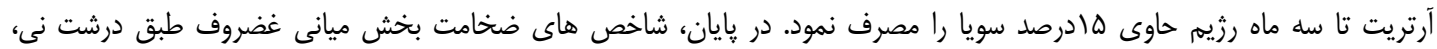

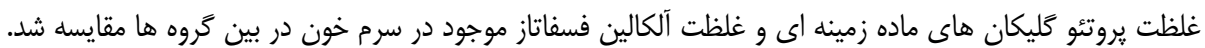

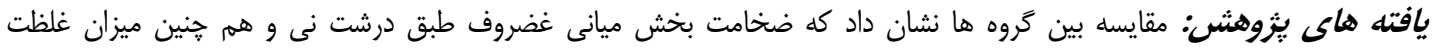

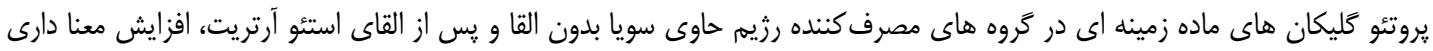

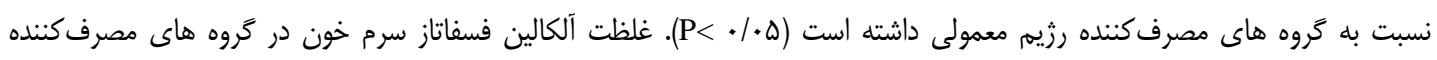

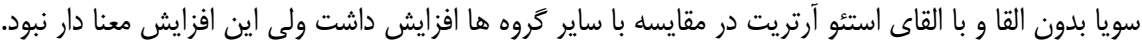

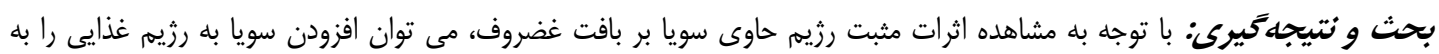

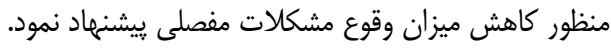

$$
\text { وازه هاى كليدى: سويا، استئو آرتريت، غضروف طبق درشت نى، هيستو مترى }
$$

Email: ztotian@ut.ac.ir

$$
\text { " نويسنده مسئول : خروه علوم بايه، دانشكده دام يزشكى، دانشخاه تهر ان، تهر ان، ايران }
$$

Copyright (C) 2017 Journal of Ilam University of Medical Science. This is an open-access article distributed under the terms of the Creative Commons Attribution international 4.0 International License (https://creativecommons.org/licenses/by-nc/4.0/) which permits copy and redistribute the material, in any medium or format, provided the original work is properly cited. 
دارويى موثرى براى بازيابى ساختار و عملكرد اوليه

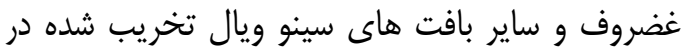
استئو آرتريت معرفى نخرديده است. نوين ترين دستور

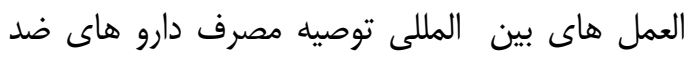

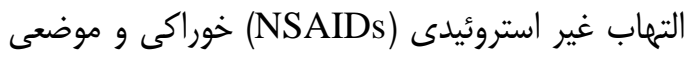

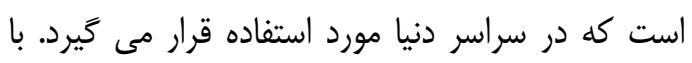

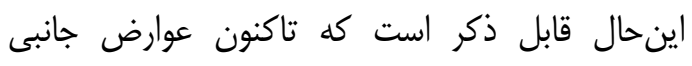

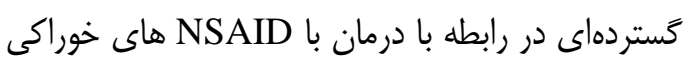

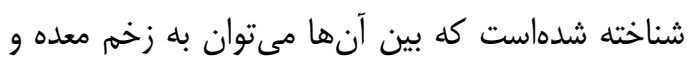

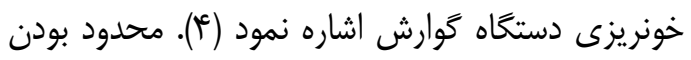

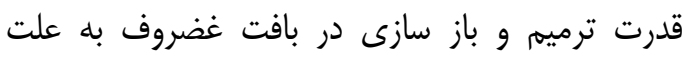

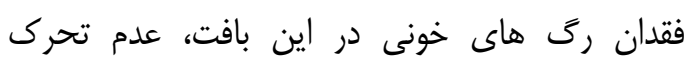

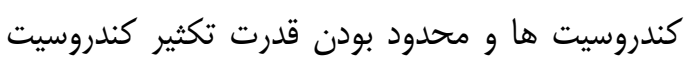
هاى بالغ از يك سو (ه) و نا كار آمدى دارو هاى موجود

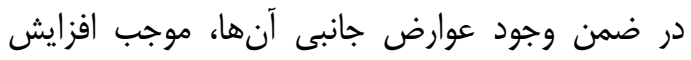

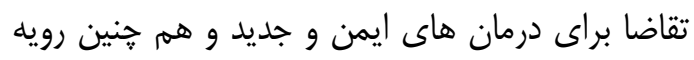

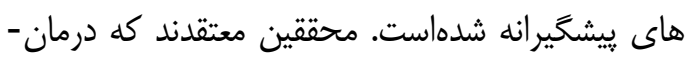

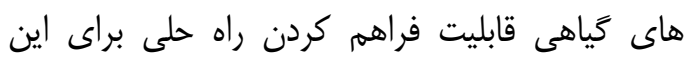

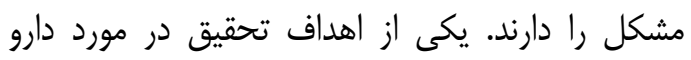

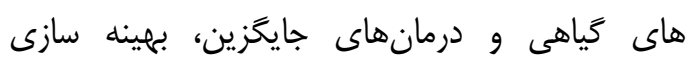
سلامت و جلوكَيرى يا به تاخير انداختن بيمارى است دان.

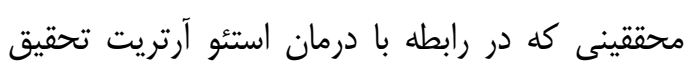
مى كنند، همواره در تلاش بوده اند تا بتوانند موثر ترين

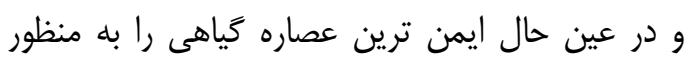

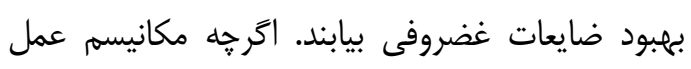

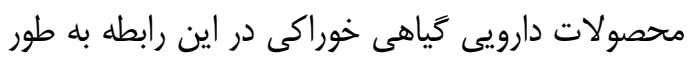

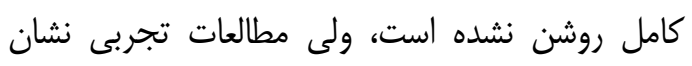

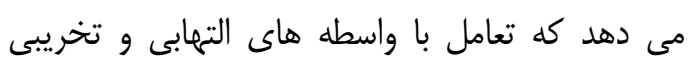
غضروف، يك مبناى منطقى براى اثر اين محصولات

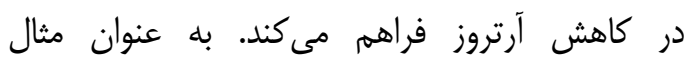
فيتواستروثن هايى كه به مقدار زياد در يروتئين سوياى فئ فئل

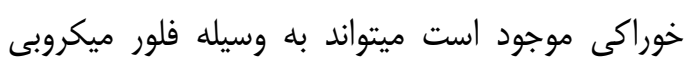

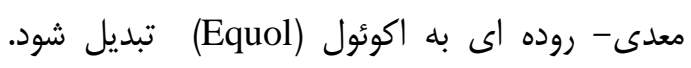

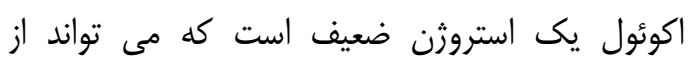
طريق تنظيم التهاب و متابوليسم استخوانى باعث

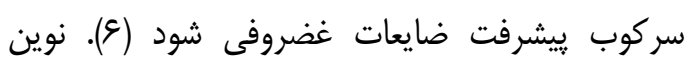

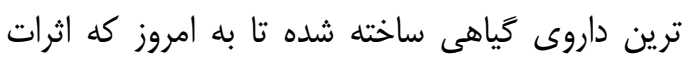

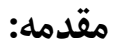

بروز جهانى بيمارى هاى وابسته به افزايش سن در

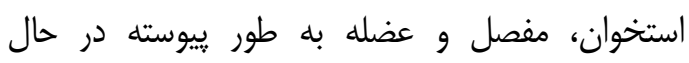
افزايش است و سلامت ميليون ها نفر در سراسر جهان را به طور جدى تهلديد مى كند. بيمارى التهابى استئو

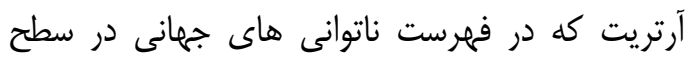
يازدهم قرار دارد، رايج ترين اختلال مفصلى است كه دان

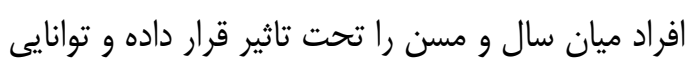

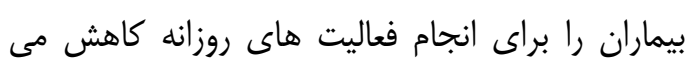

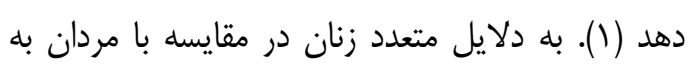
طور شديد ترى در معرض اين بيمارى هستند (T).

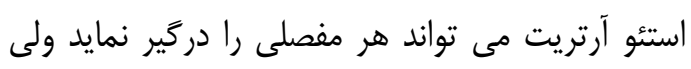

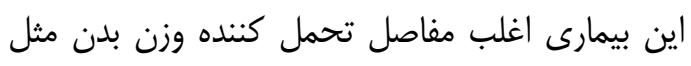

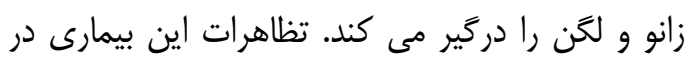
اغلب ضايعات غضروفى شامل درد، سختى و محدوديت

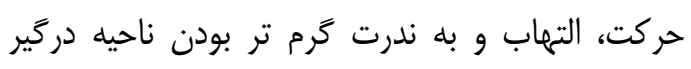

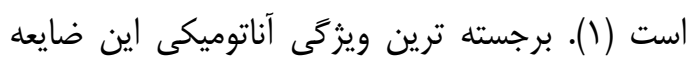

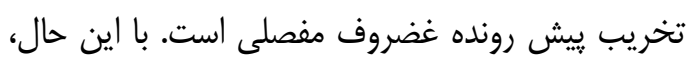

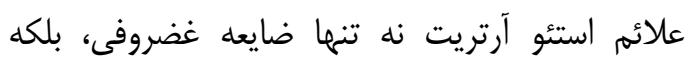

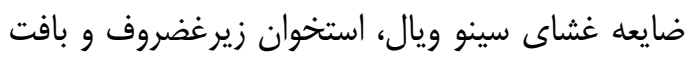

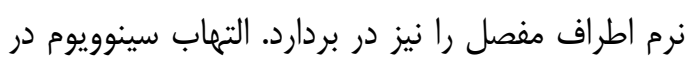

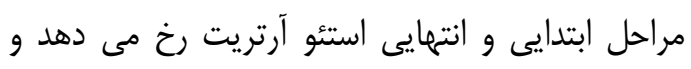
با تغييرات در غضروف مجاور مرتبط است. واسطه هاى التئ كاتابوليك و ييش التهابى مانند سيتوكين ها، اكسيد

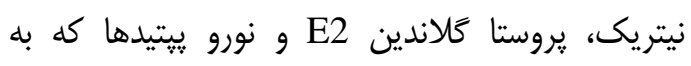

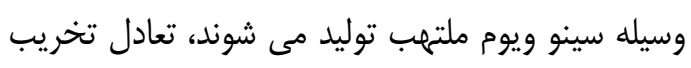

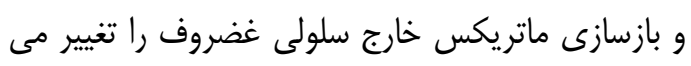

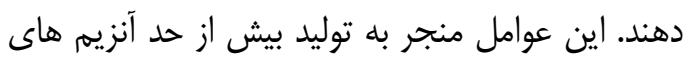

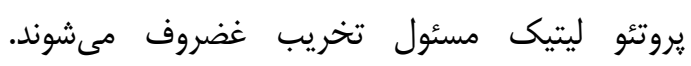

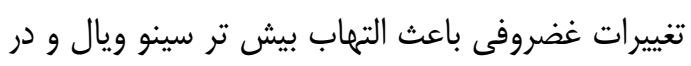

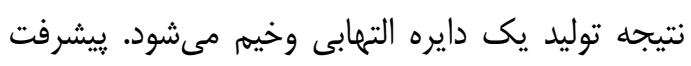

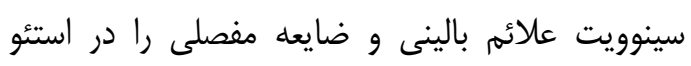

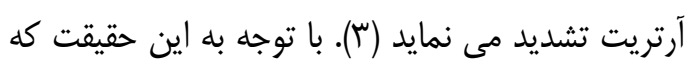
اين بيمارى اساسا يك بيمارى التهابى است، توصيه

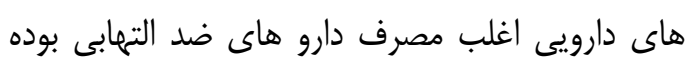

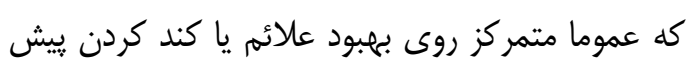
روى بيمارى است و متاسفانه تا كنون هيج درمان 
حال تاكنون اين مطالعات در سطح ثبت علائم مربوط به بهبود درد و دامنه حركت بيماران مبتلا به استئو آرتريت (TI) و يا در سطح ميكروسكويى فقط در مورد موش هاى سالم مصرف كننده رزيم هاى حاوى مقادير

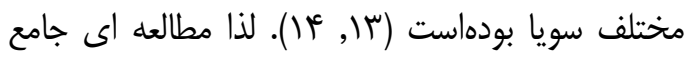
در سطح هيستو لوزى و هيستو مترى در رابطه با مقايسه اثرات رزيم حاوى سويا روى غضروف در بين موشهاى مبتلا به ضايعه غضروفى و موش هاى سالم

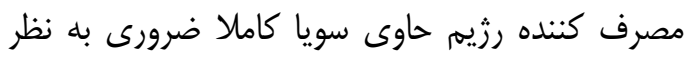
مى رسد. به اين منظور در مطالعه حاضر اثر سويا به عنوان ماده غذايى بر روى ضخامت وسط غضروف طبق درشت نى، ميزان غلظت يروتئو كليكان هاى ماده زمينه اى و هم جنين ميزان غلظت دين آلكالين فسفاتاز موجود در سرم خون موشهاى سالم و مدل استئو آرتريت مورد مطالعه و مقايسه قرار گرفت.

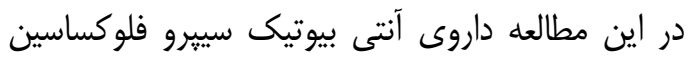

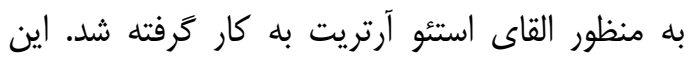
أنتى بيوتيك از رده فلورو كينولون ها (بر يايه كينولون) بوده و مطالعات مختلف حاكى از تاثير اين دارو بر كاهش كندروسيت ها و تخريب ماتريكس و حفره دار شدن غضروف مفصلى است (ها (1).

\section{مواد و روش ها}

اين مطالعه تجربى بر روى •D سر موش سورى ماده

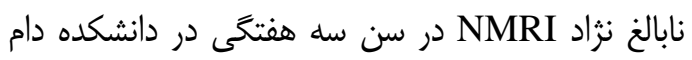
يزشكى دانشخاه تهران طى سال هوسا انجام گرفت.

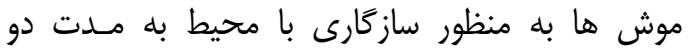

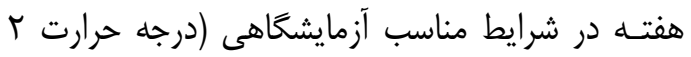

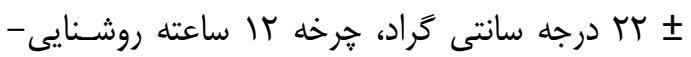
تـاريكى و دسترسى نا محدود بــهـ آب و غذا) در حيوان

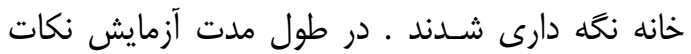

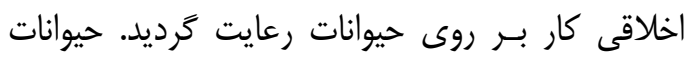

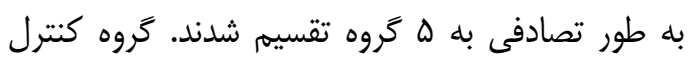
فقط آب آشاميدنى و رزيم غذايى معمولى را به مدت هاه سه ماه دريافت نمود. گروه شم به عنوان خروه مدل مدل القاى استئو آرتريت به مدت دو هفته سييرو فلو كساسين

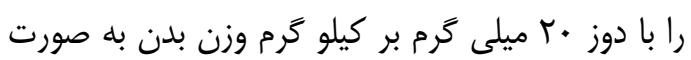

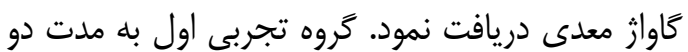

مفيد آن مورد توافق محققان زيادى هم هست، كِيسول هاى آووكادو سويا غير صابونى ( Avocado soybean (unsaponifiables آووكادو و دو سوم روغن سويا است، مىباشد. محققين معتقدند كه اين داروى كياهى در مقايسه با ساير داري دارو هاى گياهى كه تا كنون مورد مطالعه قرار گرفتهاند،

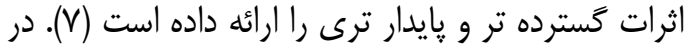

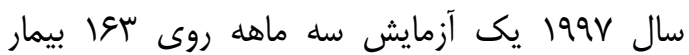

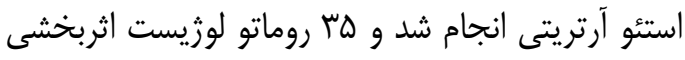

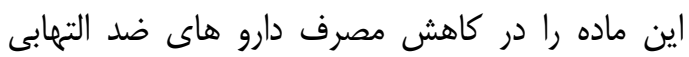
غير استروئيدى بررسى نمودند (^). در اين آزمايش برخى بيماران كيسول هاى +." ميلى گرمى حاوى ASU روزانه دريافت نمودند. در هأ روز ابتدايى دارو هاى ضد ذايك التهابى غير استروئيدى نيز تجويز شد. در هأ روز دوم

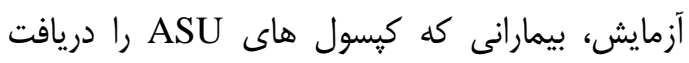
نموده بودند نسبت به گروه دريافت كننده كِيسول هاى دارو نما نياز كم ترى به دارو هاى تجويزى نشان دادند

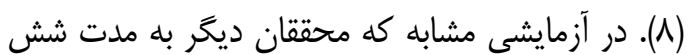

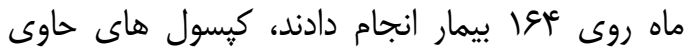

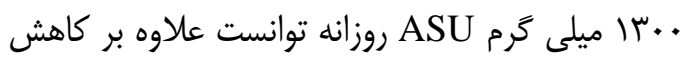
مصرف دارو هاى ضد التهاب غير استروئيدى، باعث بهبود درد و هم جنين بهبود حركت بيماران شود (9). در مطالعه اى كه بر روى گوسفندانى انجام شد كه

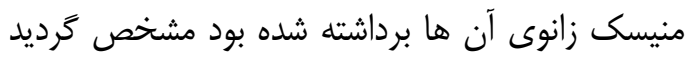

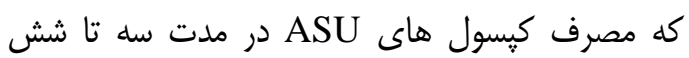
ماه مى تواند باعث افزايش معنا دارى در ضخامت غضروف زانو شود. اين يافته ها ييشنهاد مى كند كه ممكن است مخلوط آووكادو و سويا در درمان استئو

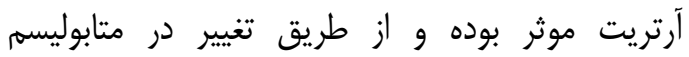
كندروسيت ها موجب تغيير در تركيبات متالو يروتئيناز،

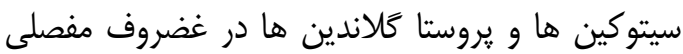

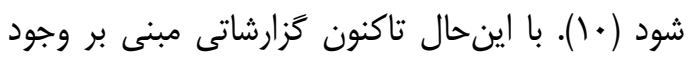

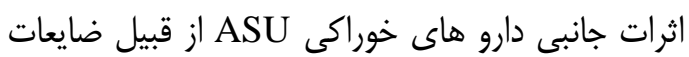
يوستى، ضايعات كبدى، ضايعات معدى - روده اى و در موارد محدود تر لخته شدن خون (I) به ثبت بله رسيده است. لذا محققين مختلفى تلاش نموده اند كه رزيم حاوى سويا را جايخزين اين كيسول ها نمايند. با اين 
كاليبره شده با ميكروسكوٍ انجام گرفت. ارزيابى مقاطع هيستو شيمى به روش درجه بندى و كمى بازى

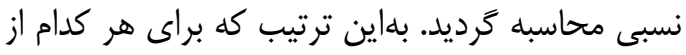

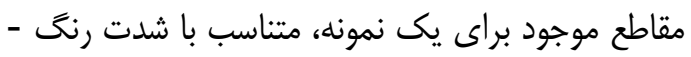
يذيرى يك درجه اختصاص داده شد و نهايتاً ميانكين براى يك نمونه ثبت گرديد. در تحليل آمارى داده هاى

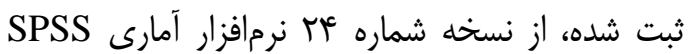

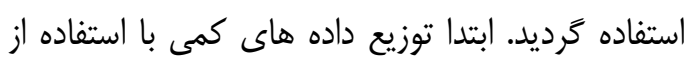

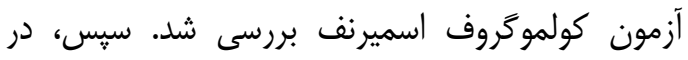

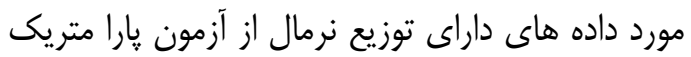
One-way ANOVA معنا دار از آزمون تعقيبى Tukey براى مقايسه تروه ها

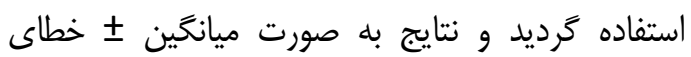
استاندارد بيان شد. جهت مقايسه كيفى ميزان يروتئو

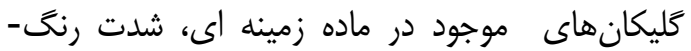
يذيرى تولوئيدين بلو مبنا قرار كرفت و از از آزمون

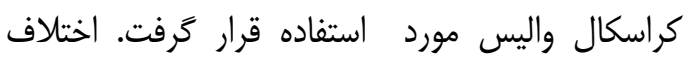

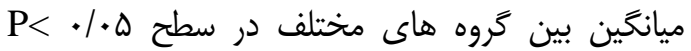
معنى دار تلقى كرديد.

\section{يافته هاى يزوهش

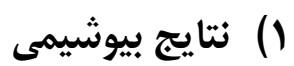

نتايج حاصل از بررسى غلظت آلكالين فسفاتاز سرم موش هاى مورد مطالعه كه در نمودار المآمده است، نشان داد كه على رغم وجود ميزان بالاى آلكالين

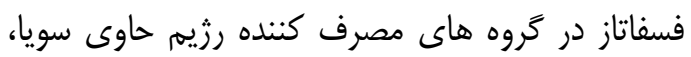
اين افزايش معنا دار نبود.
هفته سييرو فلو كساسين را مانند كروه شم دريافت نمود و به منظور بررسى احتمال ترميم خود به خودى ضايعه غضروفى با مصرف رزيم معمولى، تا سه ماه نخكا دارى

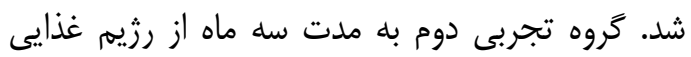
كه ها٪ آن را سويا تشكيل داد استفاده نمود. كروه

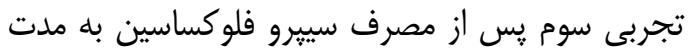
دو هفتله، به منظور بررسى احتمالى ترميه ضايعه

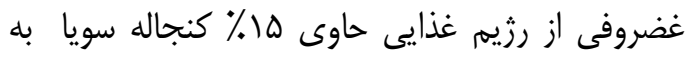

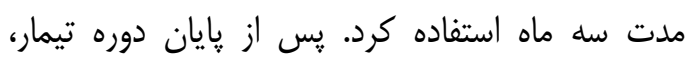
موش ها توسط كلروفرم بى هوش شده و از قلب آنها

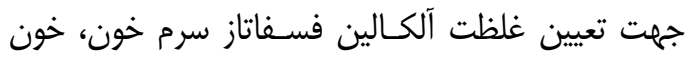

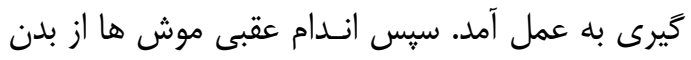

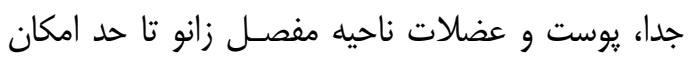
برداشته و جهت فيكس شدن در فرمالين • ا درصد قرار داده شدند. يس از كلسيه زدايى نمونسه هـا و انجـام

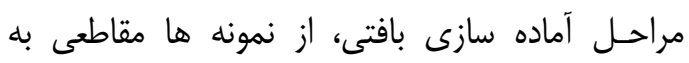

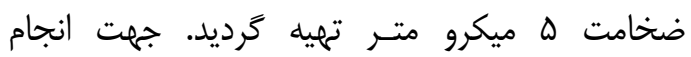

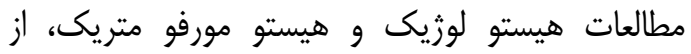

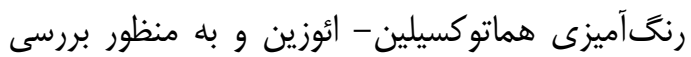
كيفى ميزان يروتئو كليكان هاى موجود در ماده زمينه - مئن

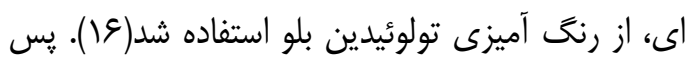

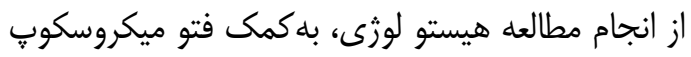

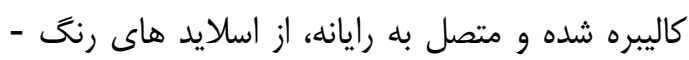

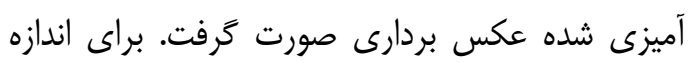

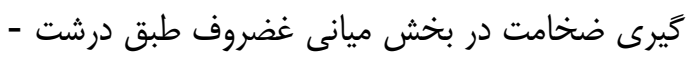

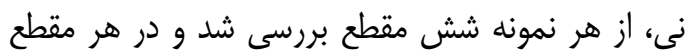

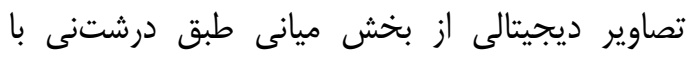

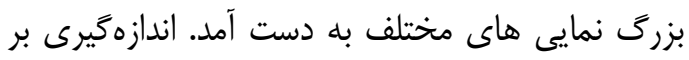

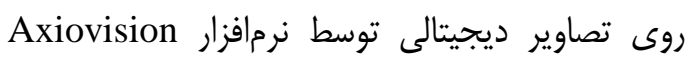

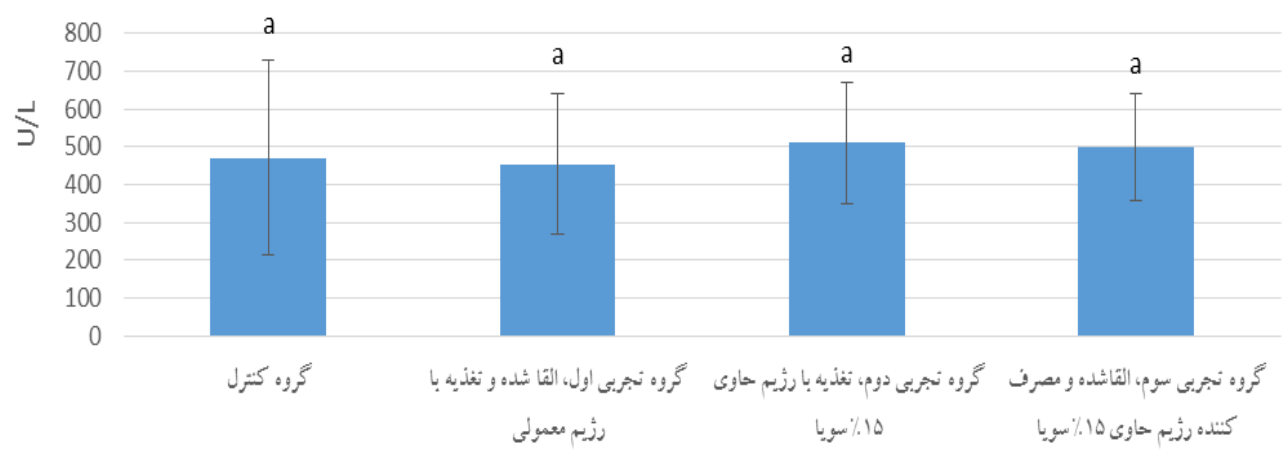

نمودار (. غلظت آلكالين فسفاتاز در سرم خون موش هاى سورى مورد مطالعه بر حسب واحد بينالمللى در ليتر (U/L). 
غضروفى در اين گروه بود. در ساير گروههاى مصرف كننده سيبروفلوكساسين كه مورد ترميم خود به به خود برد (تروه تجربى اول) يا توسط رزيم حاوى سويا (كروه

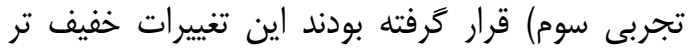

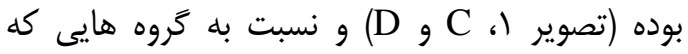

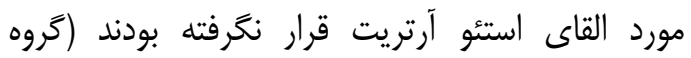

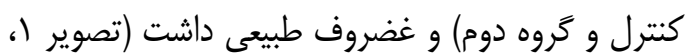
E و F F)، درجات كمى به هم ريختكى بافتى مشاهده

كرديد.

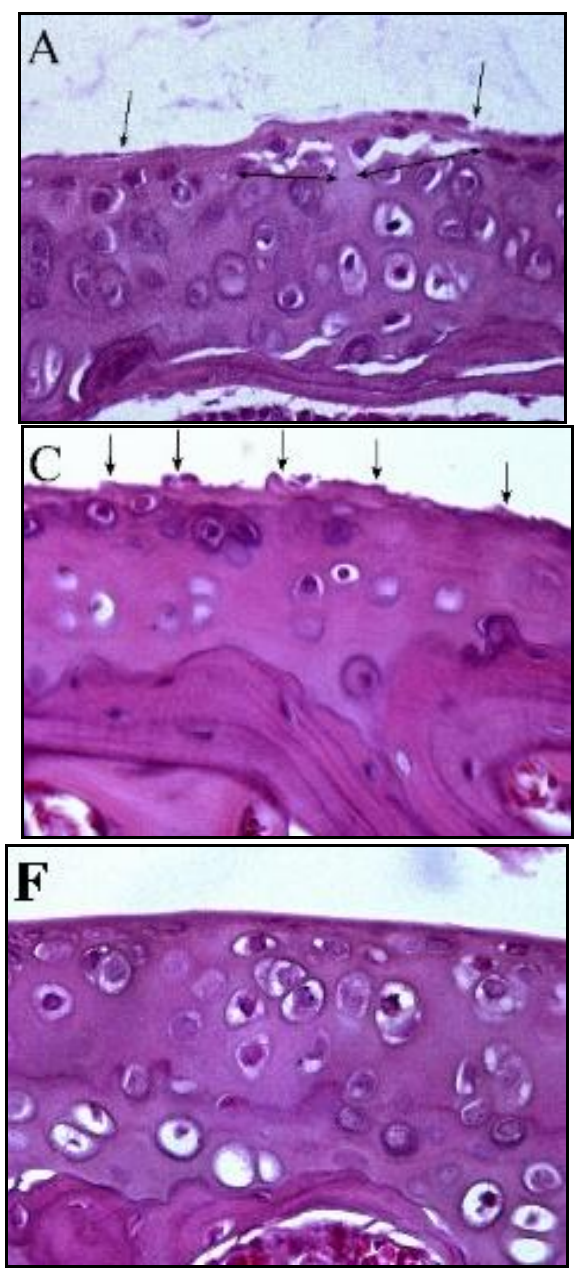

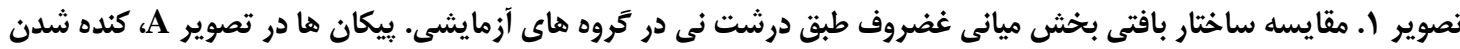

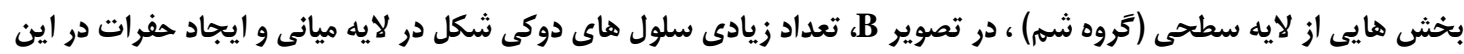

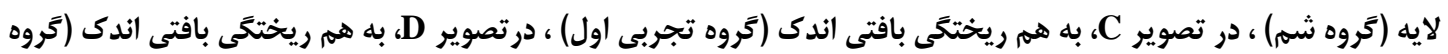

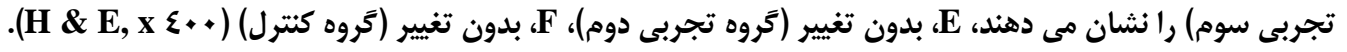

شدت كاهش رنغ يذيرى ماده زمينه اى غضروف مفصلى در گروه تجربى سوم پيكه پِ از القاى ضايعه غضروفى به مدت سه ماه از رزيم حاوى سويا مورد

\section{r) نتايج هيستو لوزى}

غضروف طبق درشت نى موش از نظر بافت شناسى در كروه كنترل شامل جهار ناحيه سطحى، ميانى، عمقى و و آهكى بود. در گروه شم، ساختار بخش ميانى غضروف طبق درشتنى، كنده شدن بخش هايى از لايه سطحى

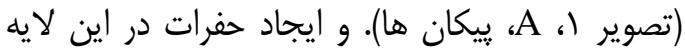

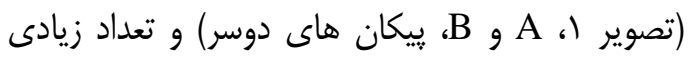
سلول هاى دوكى شكل در لايه ميانى (تصوير )، B، ييكانها) را نشان مى داد كه تاييدكننده ضايعه
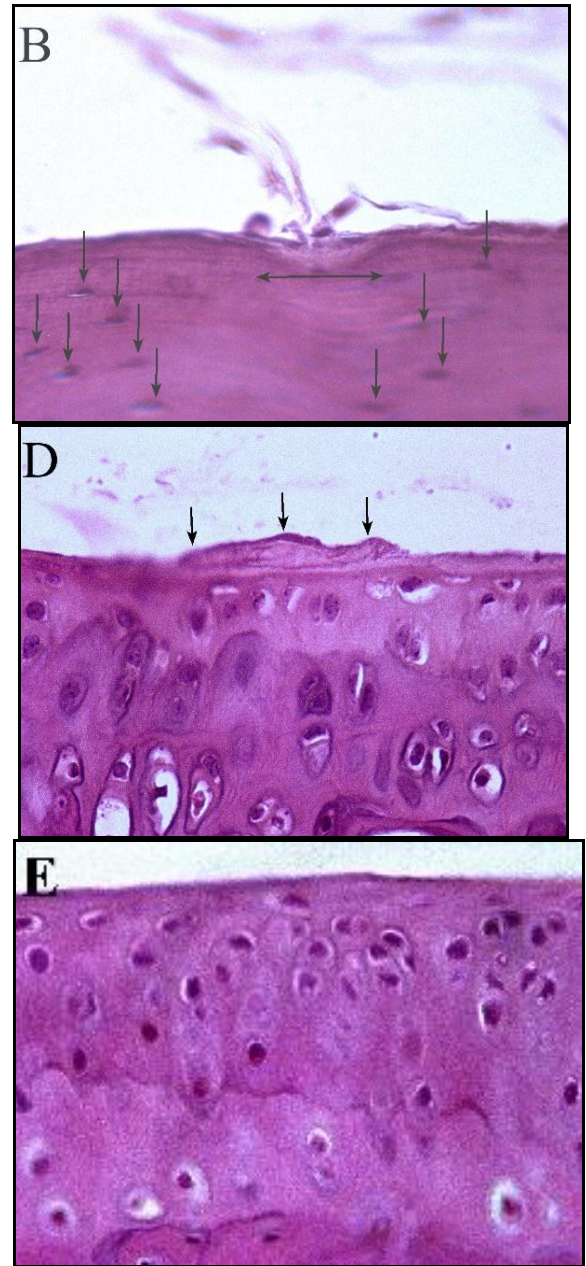
كه كم ترين ميزان كاهش رنغَ يذيرى، در گروه تجربى دوم كه بدون القاى ضايعه غضروفى از رزيم

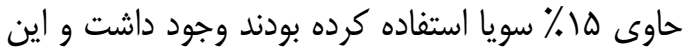

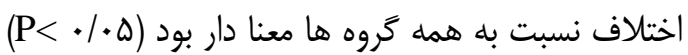

$$
\text { (تصوير r، C C ( C). }
$$

مصرف قرار داده بودند، نسبت به كروه تجربى اول كه رزيم غذايى معمولى را يس از القاى ضايعه دريافت

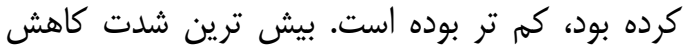

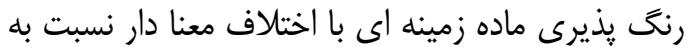
ساير گروه ها، در گروه شم (مدل القاى ضايعه

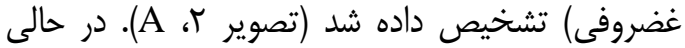

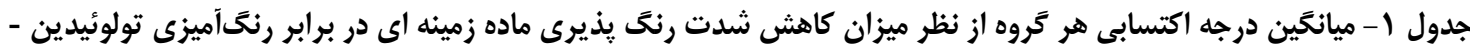

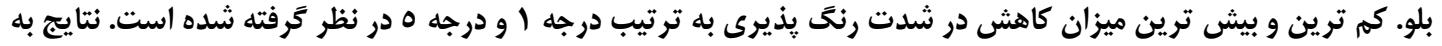

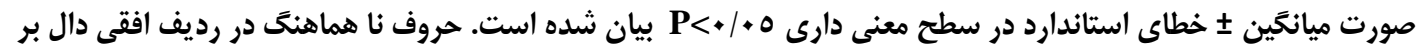
اختلاف معنى دار است.

\begin{tabular}{|c|c|c|c|c|c|}
\hline كروه تجربى سوم، القاى & كروه تجربى دوم، تغذيه & كروه تجربى اول، القاى & كروه شم، تاييد القاى & كروه كنترل، & كروههاى \\
\hline ضايعه غضروفى و تغذيه & با رزيم حاوى ها ٪ سويا & ضايعه غضروفى و تغذيه & ضايعه غضروفى & مصرف رثيم & موردمطالعه \\
\hline با رزيم حاوى ه1\% سويا & & با رزيم معمولى & & معمولى & \\
\hline$T / T I \pm 1 / \cdot \cdot^{b}$ & $1 / r \pm \cdot / M^{c}$ & $r / \Lambda \pm \cdot / 9 q^{b}$ & $r / \Delta \pm \cdot / V)^{a}$ & $r / r \cdot \pm \cdot / \Lambda r^{b}$ & درجه اكتسابى \\
\hline
\end{tabular}

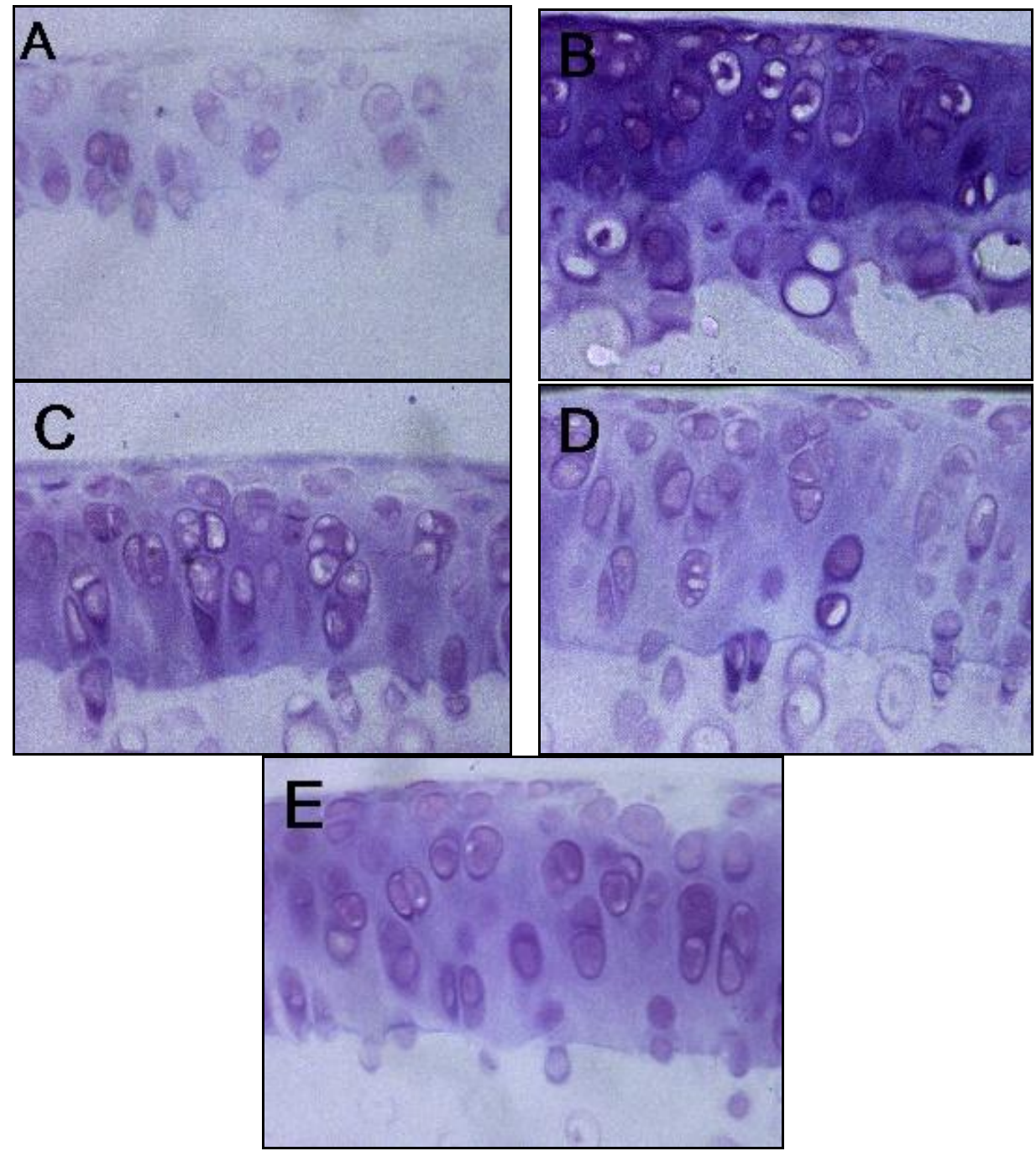

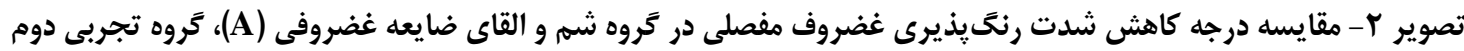

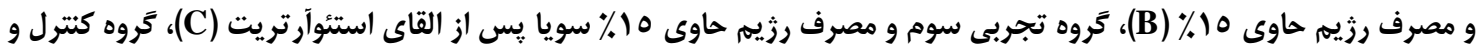

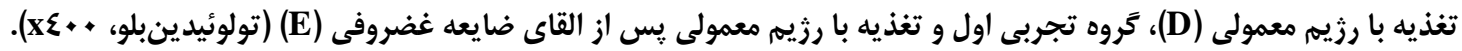


گروه هاى كنترل و تجربى اول كه از رزيم معمولى

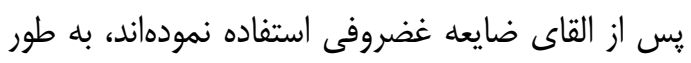

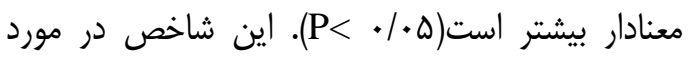

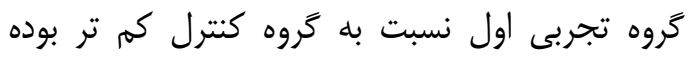
است كه البته اين اختلاف معنا دار نبوده است (نمودار ب ترون و تصوير 3).

\section{ع) نتايج هيستو مترى}

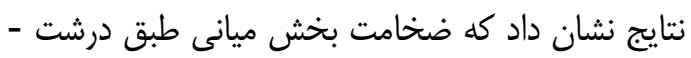

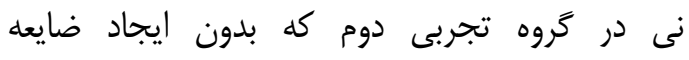
غضروفى از رزيم حاوى سويا استفاده كرده بودند نسبت

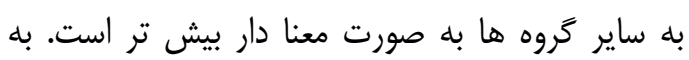

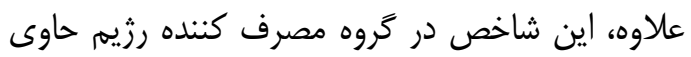

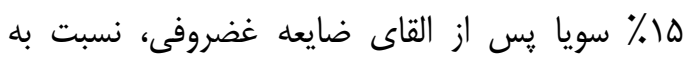

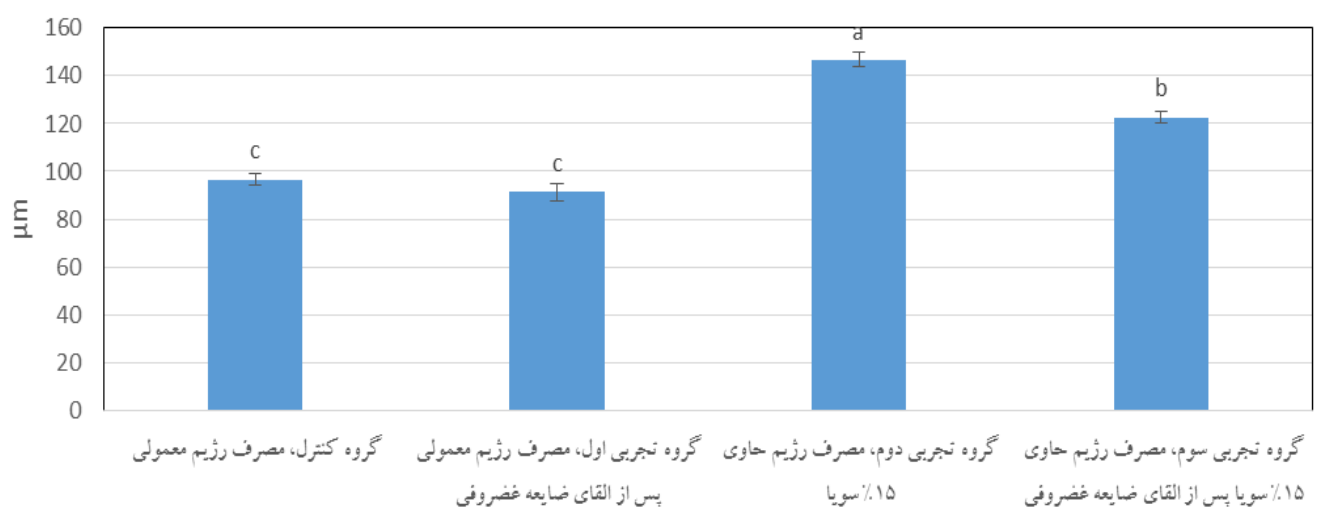

نمودار r. مقايسه ميانتين ضخامت بخش ميانى غضروف طبق درشت نى در تروه هاى آزمايشى. حروف نا هماهنَ دال بر اختلاف

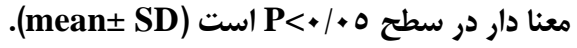
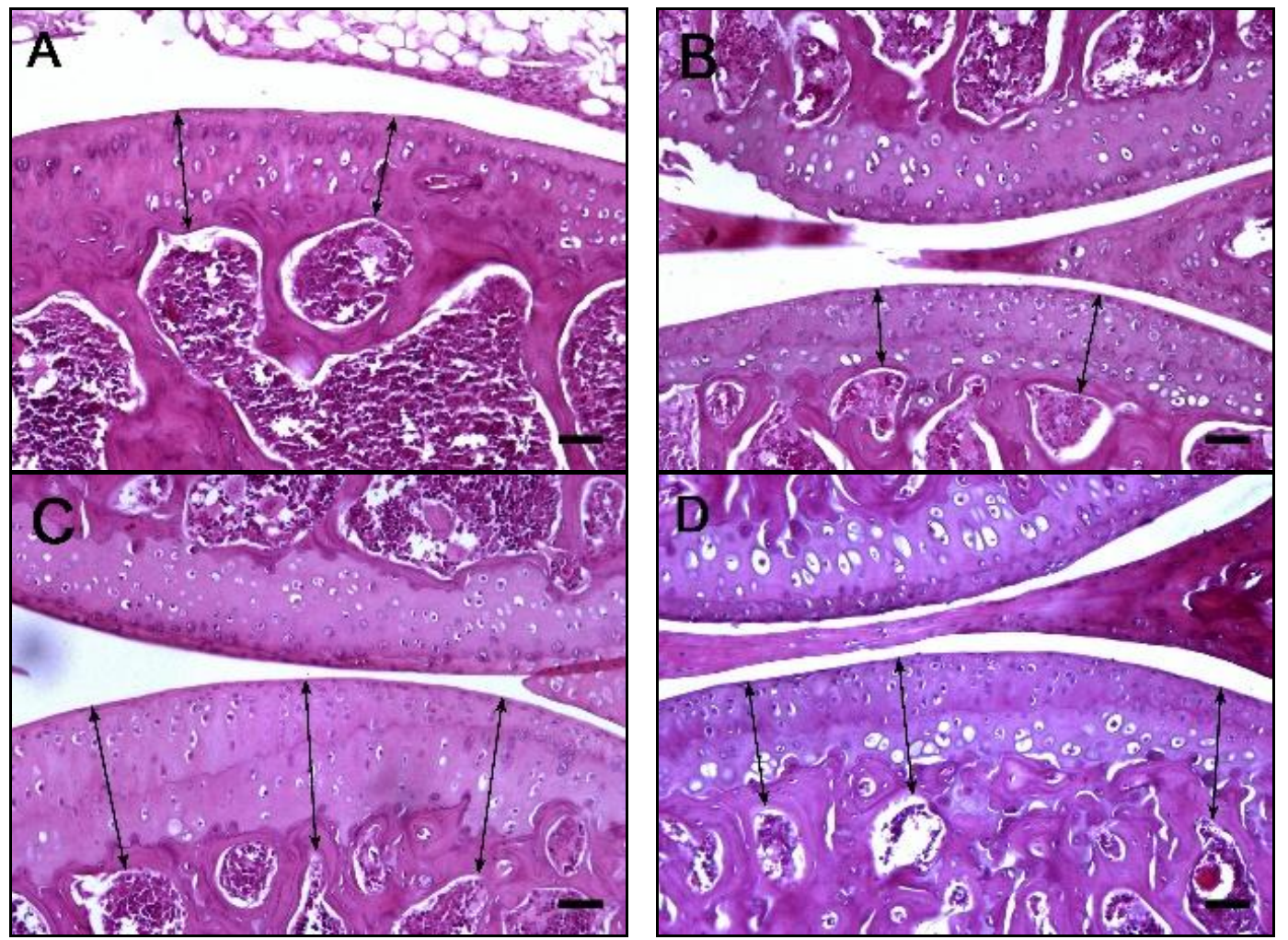

تصوير س. مقايسه ضخامت بخش ميانى غضروف طبق درشت نى در تروه كتترل (A)، تروه تجربى اول و تغذيه با رزيم معمولى

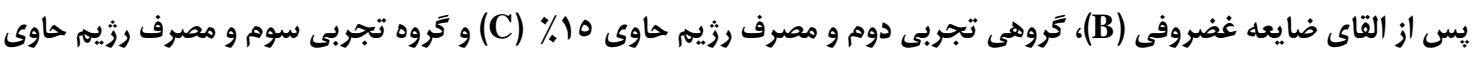




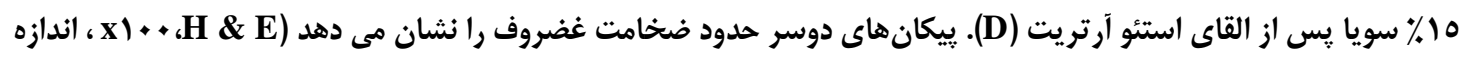
خط مقياس: +0 (0 ميكرو متر).

حاكى از اثرات بهبود دهنده اين ماده غذايى در مقايسه

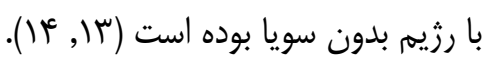

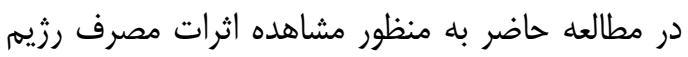

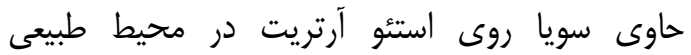

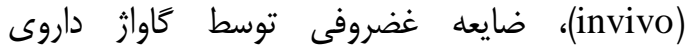

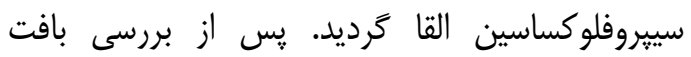
شناسى غضروف طبق درشتنى در گروه هاى مختلف،

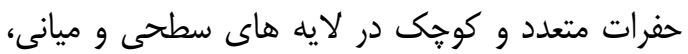
كنده شدن بخش هايى از لايه سطحى و دوكى شدن

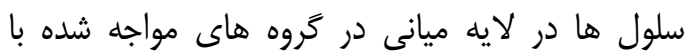

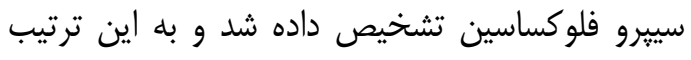
القاى ضايعه غضروفى توسط داروى سييرو فلوكساسين

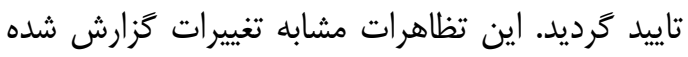
در مطالعات ساير محققينى است كه تشكيل شكاف و

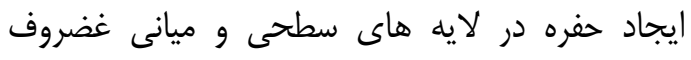
مفصلى موش هاى صحرايى نا بالغ را متعاقب تجويز

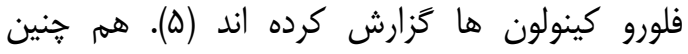
محققين ديگر كاهش ضخامت در غضروف صفحه رشد و غضروف مفصلى موش هاى صحرايى را متعاقب داقي تجويز هفت روز سيبرو فلوكساسين گزارش كردهاند. اين محققين كاهش ضخامت غضروف را به دليل اثر مهار كننده سييرو فلوكساسين بر ميتوز سلول هاى فين

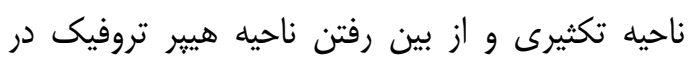
غضروف صفحه رشد تفسير كرده اند. نتايج حاصل از مطالعه هيستو متريك نشان داد كه ضخامت بخش ميانى طبق درشتنى نه تنها در گروه موش هاى سالم

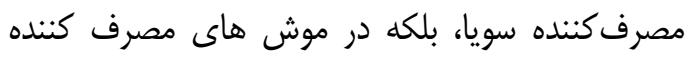

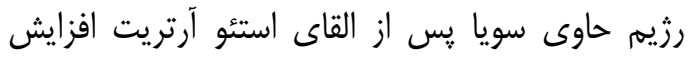

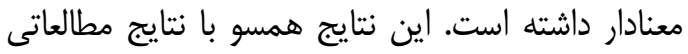
است كه روى موشهاى سورى مواجه شده با رزيم

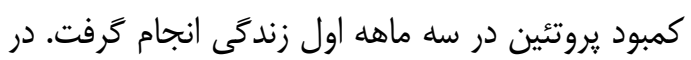
اين مطالعه محققين گزارش نمودند كه تيمار با رزيم حاوى يروتئين كامل حاوى سويا در سه ماهه دوم دان زندگى اين موش ها در مقايسه با تيمار با رزيم حاوى

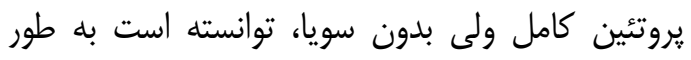

\section{بحث و نتيجل كيرى}

ميزان وقوع بالاى مشكلات مفصل زانو و لكن در

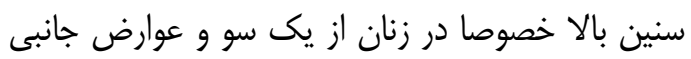
ناشى از مصرف دارو هاى موجود از سوى ديخر باعث

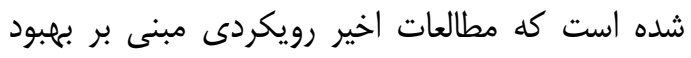
اين ضايعات به وسيله رزيم غذايى را در ييش بخيرند

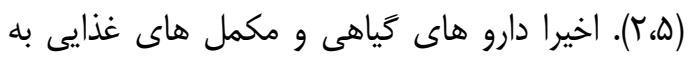

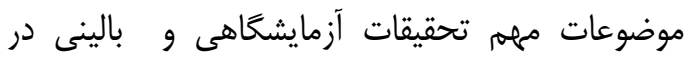
ارتويدى و روماتو لوزى تبديل شده اند. بنابراين اطلاع

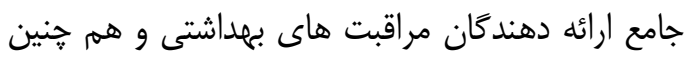

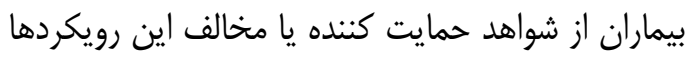
حائز اهميت زيادى است. تحقيقات منتشر شده مختلفى إنى

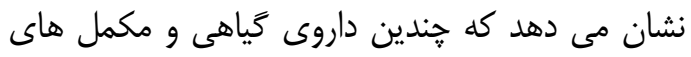
غذايى توانايى كاهش درد در بيماران مبتلا به استئو

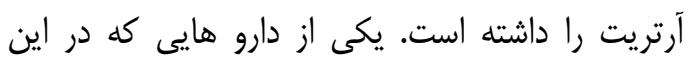

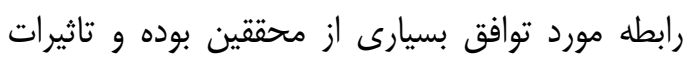

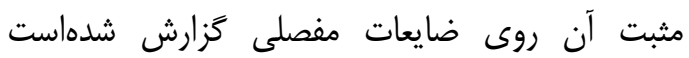

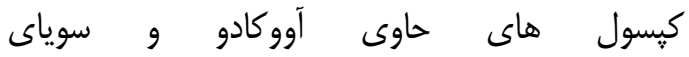
غيرصابونى(ASU) است. با اين حال محققينى كه در أورات

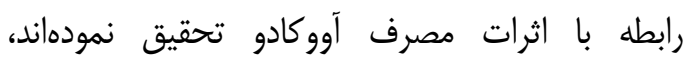

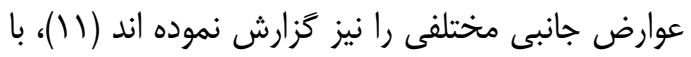
توجه به اينكه كِيسول هاى ASU حاوى تنها يك

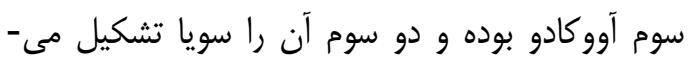
دهد، محققين زيادى تلاش نمودهاند تا مصرف سويا به عنوان يك ماده غذايى را جايكزين اين تركيب نمايند. اولين مطالعه روى مصرف بلند مدت يروتئين سويا بـانه

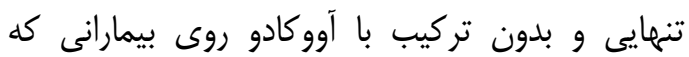

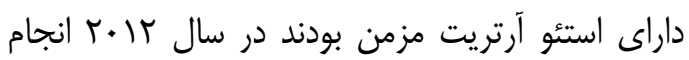

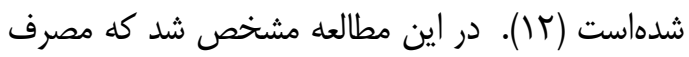

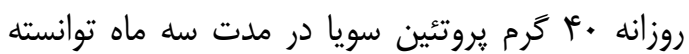

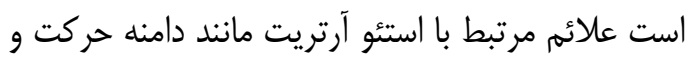

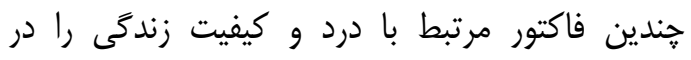

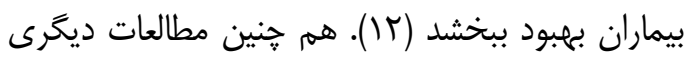
كه در رابطه با اثر رزيم حاوى سويا روى غضروف طبق بن درشتنى در موش هاى سورى ماده انجام كَرفته است 
و در نتيجه از تخريب كندروسيت ها و سلول هاى سينو ويال جلوگيرى مى نمايد (19). از طرف ديخر لازم به ذكر است كه در مطالعه اي كه روى ميمون هاى اواركتومى شده انجام شد، مصرف سه ساله سويا در اين

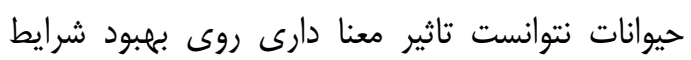

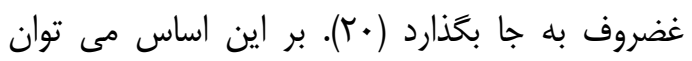
جنين نتيجه كيرى كرد كه مصرف مزمن و بلند مدت رزيم حاوى سويا اثر مثبت مضاعفى روى ضخامت

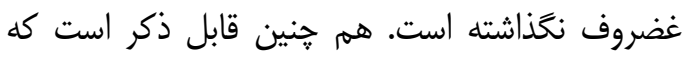
محققين ديخر نشان دادند كه كه سويا نتوانسته است به تنهايى جايگزين مناسبى در موارد ضايعه غضروفى كه

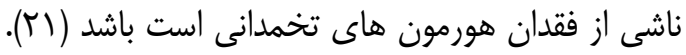

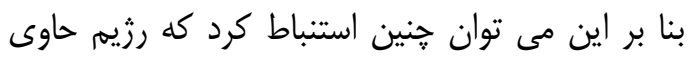

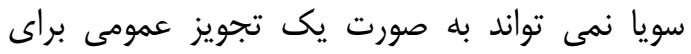
همه انواع ضايعات غضروفى استفاده شود. شاخص ديخرى كه در مطالعه حاضر مد نظر قرار گرفت مقايسه

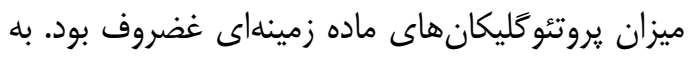

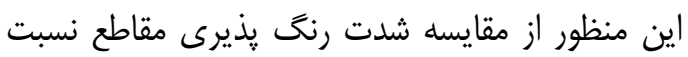
به تولوئيدين بلو استفاده كرديد. تولوئيدين بلو به صورت اختصاصى يروتئو كليكان ها را رنخ مى كند و ميزان شدت جذب رنگ تولوئيدين بلو توسط ماده زمينه اى غضروف مفصلى، مى تواند نشان دهنده ميزان يروتئو

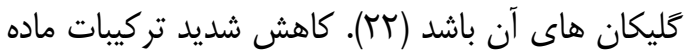
زمينه اى به ويزه يروتئو كليكان ها، زمينه ساز بروز

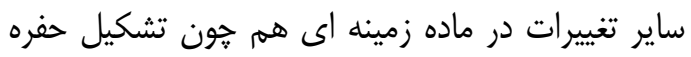

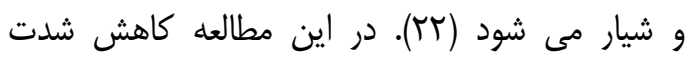
جذب رنغَ تولوئيدين بلو توسط ماده زمينه اى غضروف مفصلى و هم جنين حفره هاى متعدد و به هم ريختكى نه هاى بافتى در كروه هاى مواجه شده با سيبرو

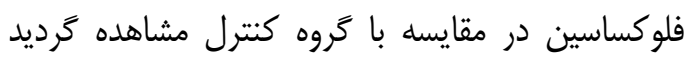
كه اين علايم نشان دهنده كاهش محتواى يروتئو كليكان هاى ماده زمينه ای در اين گروه بوده است.

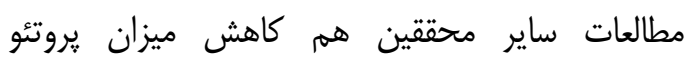
كليكان هاى ماده زمينه اى غضروف مفاين مفصلى متعاقب مصرف فلورو كينولون ها را تأييد مى كند (سآ). كزارش شدهاست كه كاهش :بروتئو كليكان هاى ماده زمينه اي به علت عملكرد مهار كننده كينولون ها بر روى سنتز يروتئو كليكان ها در كندروسيت ها مى باشد. با اين وجود
معنا دارى باعث افزايش ضخامت بخش ميانى غضروف

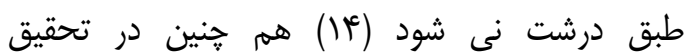

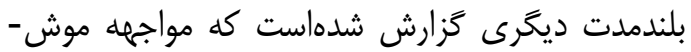
هاى سورى سالم با رزيم غذايى حاوى • ب درصد سويا

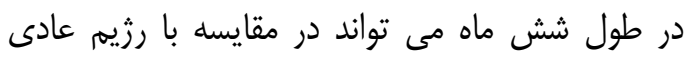

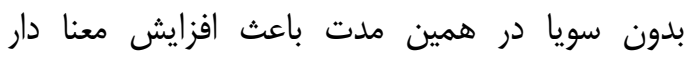
ضخامت بخش ميانى غضروف طبق درشت نى شود (سا). نتايج مطالعه حاضر مى تواند نشان دهد كهان

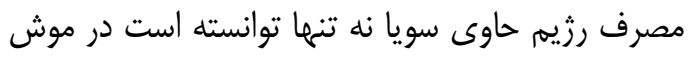

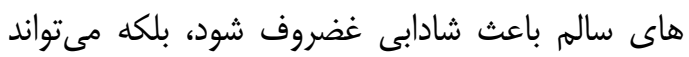

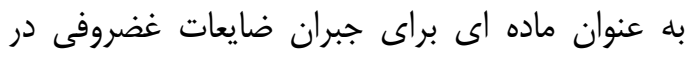

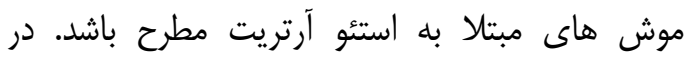
مطالعه اى كه به منظور كشف خاصيت سويا در بهببود بيمارى هاى مفصلى انجام گرفت، برخى محققين اين اثرات را مرتبط با آنتى اكسيدان گياهى موجود در سويا

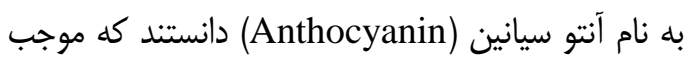
كاهش تعداد سلول هاىTh17 و هم جنين سطح توليد

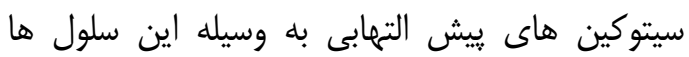
كشته است. به علاوه اين محققين اظهار نمودند كه اين آنتى اكسيدان توانسته است سطح اكسيداتيو

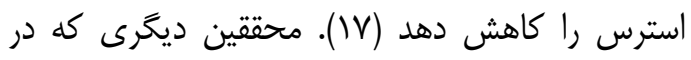
رابطه با اثر دو ايزو فلاون موجود در سويا به نام هاى دهن دائري دايدزين (Daidzein) و و جنيستئين (Genistein) مطالعه نموده اند بيان نمودند كه احتمالا مكانيسم اثر

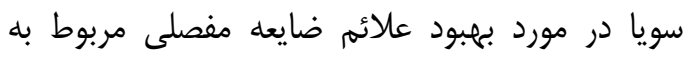

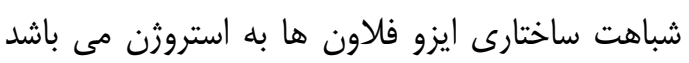
(1). در اين رابطه تزارشاتى نيز در زمينه اثر عصاره

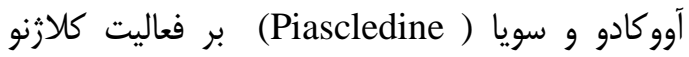
ليتيك كندروسيت هاى غضروف مفصل خرگّش در در

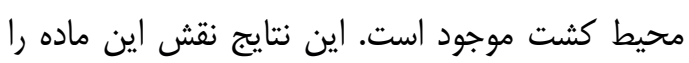
در محدود كردن اثر زيان آور ايتترلوكينا در بيمارى اين

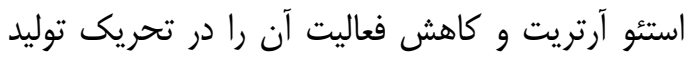

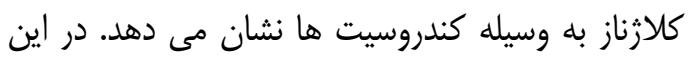

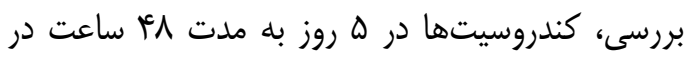
محيط كشت داراى Piascledine به ميزان •ا ميكرو كرم بر ميلى ليتر قراركرفتند. نتايج نشان داد كه اين

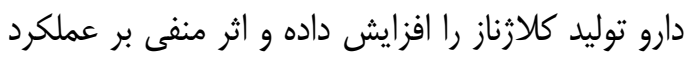
اينترلوكين از طريق كاهش ظرفيت سيتوكاين ها داشته 
تغذيه شدند انجام گرديد، بيان شد كه غلظت يروتئو كليكان ها در غضروف هيج تغيير معنا دارى نداشته

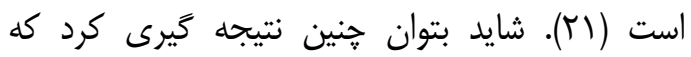

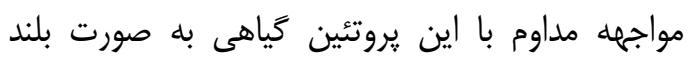

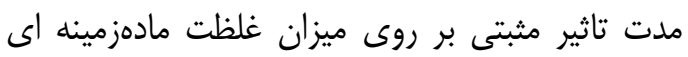
غضروف نمى كذارد. در رابطه با غلظت آلكالين فسفاتاز موجود در سرم موش هاى موردآزمايش در اين مطالعاله،

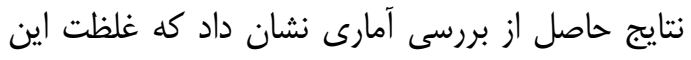

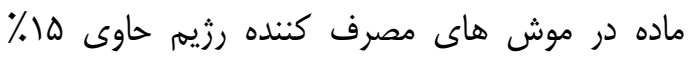
سويا بيش تر بوده است. با توجه به اين كه در اين كروه ضخامت غضروف طبق درشتنى نيز افزايش داشته

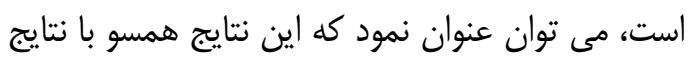

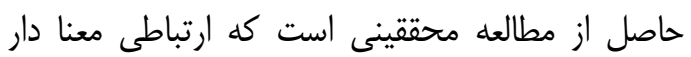

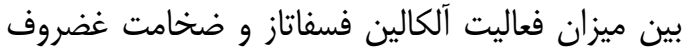

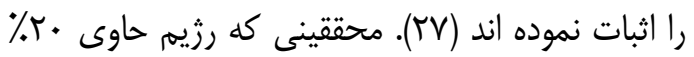

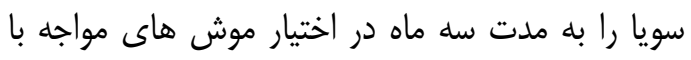
كمبود يروتئين قرار دادهاند نيز افزايش معنا دار آلكالين

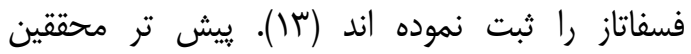

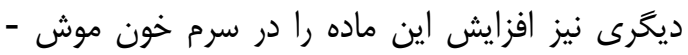
هاى صحر ايى متعاقب مصرف مكمل هاى كياهى مانند

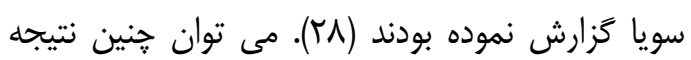
كيرى كرد كه سويا قادر است با تاثير افزايشى روى نون آلكالين فسفاتاز كه شاخصى براى تعيين سلامت فادي كندروسيت ها با نقش كانى سازى غضروف به به شمار

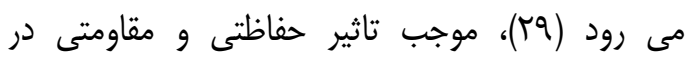
غضروف گردد. مطالعه حاضر نشان داد كه تغذيه با روان رزيم حاوى ها٪ سويا توانسته است نه تنها باعث

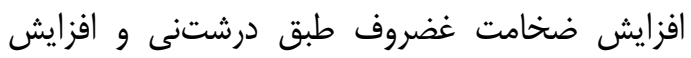

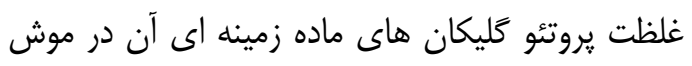
هاى سالم شود، بلكه توانسته است تا حدودى باعث تخفيف اثرات ضايعه غضروفى در مدل هاى القاى

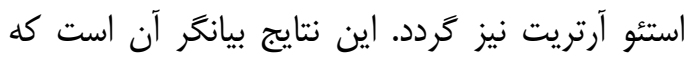
اضافه كردن سويا به رزيم غذايى توانسته است بر برد

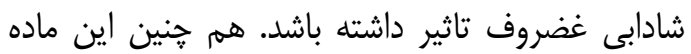
غذايى مى تواند حداقل در كنار تجويز دارو هاى شيميايى شناخته شده براى اين بيمارى مصرف شود. اين رويكرد مى تواند باعث كاهش دوز مصرفى دارو ها بان بيمارى مصرف
مطالعات قديمى تر، كاهش يروتئو كليكان ها را به علت

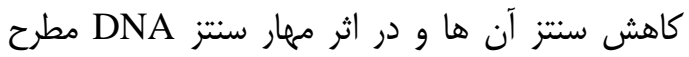

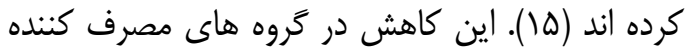

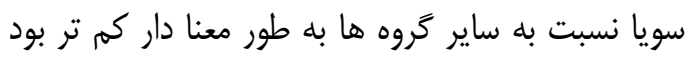
كه مى توان بيان كرد كه رزيم حاوى سويا توانسته است موجب ايجاد تاثير محافظتى در برابر القاى ضايعه غضروفى شود و يا تاثير مثبى روى جبران ضايعه

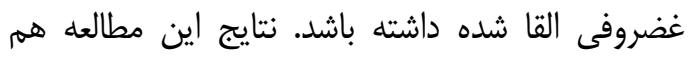
خوان با مطالعه ديخرى است كه نشان داده است كه ميزان غلظت يروتئو گليكان هاى موجود در ماده زمينه اى غضروف در موش هاى سالم مصرفكننده رزيم

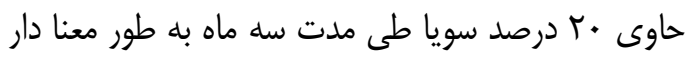

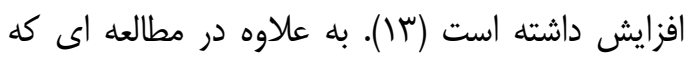
روى موش هاى مصرف كننده داروى كيسول هاى ASU

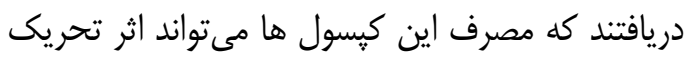

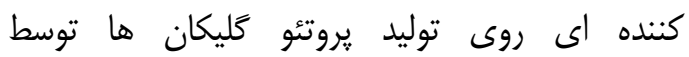
كندروسيت ها داشته باشد (V). هم جنين در مطالئ

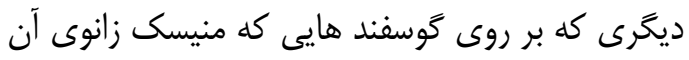
ها برداشته شده بود و بله مدت سه كاه ماه باه

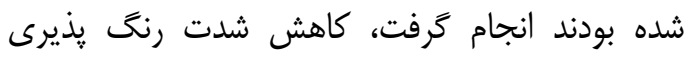

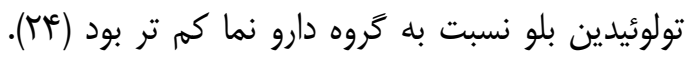
محققين ديخرى كه گزارش نموده اند كه آووكادو سويا

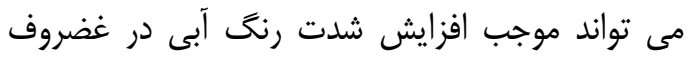

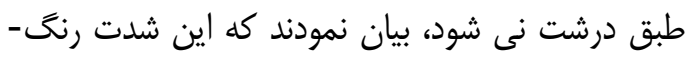
يذيرى مىتواند به علت كاهش كاتابوليسم يا افزايش آنابوليسم باشد. جنانجه يِيش تر يِيشنهاد نموده بودند

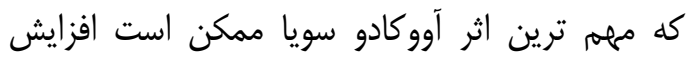

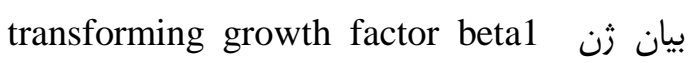
and beta2 سلولى توسط كندروسيت ها مى محققان اظهار نمودهاند كه Tranforming growth توانستهاست باعث تحريك بيو سنتز كلازن و كليكوز آمينوكليكان ها در كندروسيت هاع تهاى

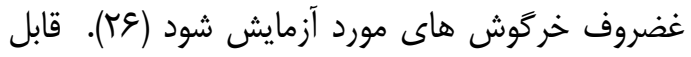

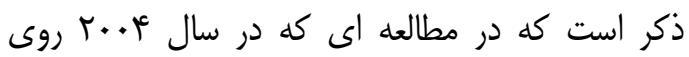

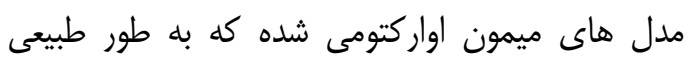
مبتلا به استئو آرتريت بودند و به مدت اله سه سال با سويا 


$$
\text { اثرات جانبى مصرف بلندمدت اين دارو ها شود. }
$$

يا طول دوره درمان شود و به اين واسطه باعث كاهش

\section{References}

1.Cross M, Smith E, Hoy D, Nolte S, Ackerman I, Fransen M, et al. The global burden of hip and knee osteoarthritis: estimates from the global burden of disease 2010 study. Annal Rheum Dis 2014;73:1323-30.

2.Hame SL, Alexander RA. Knee osteoarthritis in women. Curr Rev Musculoskel Med 2013;6:182-7.

3.Sellam J, Berenbaum F. The role of synovitis in pathophysiology and clinical symptoms of osteoarthritis. Nature Rev Rheumatol2010;6:625-35.

4.Varga Z, Sabzwari SRA, Vargova V. Cardiovascular risk of nonsteroidal antiinflammatory drugs an under recognized public health issue. Cureus2017;9:1144.

5.Hardingham T, Tew S, Murdoch A. Tissue engineering chondrocytes and cartilage. ArthRes Therap2002;4: 63.

6.Lin IC, Yamashita S, Murata M, Kumazoe M, Tachibana H. Equol suppresses inflammatory response and bone erosion due to rheumatoid arthritis in mice.

J Nutri Biochem2016;32:101-6.

7.Angermann P. Avocado/soybean unsaponifiables in the treatment of knee and hip osteoarthritis. Ugeskrift Laeg2005;167:3023-5.

8.Blotman F, Maheu E, Wulwik A, Caspard H, Lopez A. Efficacy and safety of avocado soybean unsaponifiables in the treatment of symptomatic osteoarthritis of the knee and hip. A prospective multicenter three month randomized, double blind placebo controlled trial. Rev Rhum 1997;64:825-34. 9.Maheu E, Mazieres B, Valat JP, Loyau G, Loet XL, Bourgeois P, et al. Symptomatic efficacy of avocado soybean unsaponifiables in the treatment of osteoarthritis of the knee and hip a prospective, randomized, double blind, placebo controlled multicenter clinical trial with a six month treatment period and a two month followup demonstrating a persistent effect. Arth Rheumatol1998;41:81-91.

10.Lippiello L, Nardo JV, Harlan R, Chiou T. Metabolic effects of avocado soy unsaponifiables on articular chondrocytes. Evid Based Comple Alt Med 2008;5:191-7. 11.Olivier P, Montastruc JL. Post marketing safety profile of avocado soybean unsaponifiables. Pres Med Paris France2010;39:211-6.

12.Arjmandi BH, Khalil DA, Lucas EA, Smith BJ, Sinichi N, Hodges SB, et al. Soy protein may alleviate osteoarthritis symptoms. Phytomedi Int J Phytotherap Phytopharmacol2004;11:567-75.

13.Fazelipour S, Tootian Z, Matini E, Hadipour Jahromy M. Histomorphometric alteration of knee articular cartilage and serum alkaline phosphatase in young female Mice by chronic supplementation with soybean. Phytotherapy ResPTR 2011;25:886-91.

14.Tootian Z, Fazelipour S, Sheibani M, Kiaei S. The effect of soybean meal on the maintenance of cartilage in animal knee joints. J Vet Res 2012;67:49-52.

15.Burkhardt JE, Hill MA, Carlton WW,

Kesterson JW. Histologic and histochemical changes in articular cartilages of immature beagle Dogs dosed with difloxacin a fluoroquinolone. $\mathrm{Ve}$ Pathol1990;27:162-70.

16.Maslanka T, Jaroszewski JJ, Mikolajczyk A, Rotkiewicz T. Effect of increasing doses of enrofloxacin on chicken articular cartilage. Pol J Vet Sci2009;12:2133.

17.Min HK, Kim SM, Baek SY, Woo JW, Park JS, Cho ML, et al. Anthocyanin extracted from black soybean seed coats prevents autoimmune arthritis by suppressing the development of th17 cells and synthesis of proinflammatory cytokines by such cells via inhibition of NF kappaB. Plos One 2015;10:138201.

18.Mohammadshahi M, Haidari F, Rashidi B, Saei AA, Mahboob S, Rashidi MR. Comparison of the effects of genistein and daidzein with dexamethasone and soy protein on rheumatoid arthritis in Rats. Bio Impacts 2011;1:161-70.

19.Mauviel A, Loyau G, Pujol JP. Effect of unsaponifiable extracts of avocado and 
soybean Piascledine on the collagenolytic action of cultures of human rheumatoid synoviocytes and Rabbit articular chondrocytes treated with interleukin-1. Rev Rhum Malad Osteoarticul 1991;58:241-5.

20.Ham KD, Loeser RF, Lindgren BR, Carlson CS. Effects of long term estrogen replacement therapy on osteoarthritis severity in cynomolgus monkeys. Arth Rheum2002;46:1956-64.

21.Ham KD, Oegema TR, Loeser RF, Carlson CS. Effects of long-term estrogen replacement therapy on articular cartilage IGFBP-2, IGFBP-3, collagen and proteoglycan levels in ovariectomized cynomolgus monkeys. Osteoarth Cartil2004;12:160-8.

22.Jacobs JW, Rasker JJ, Bijlsma JW. Alternative medicine in rheumatology: threat or challenge? Clin Exp Rheumatol2001;19:117-9.

23.Jacobs JW, Rasker JJ, Riel PL, Gribnau FW, Putte LB. Rheumajecta and vasolastine in the treatment of rheumatoid arthritis the results of a placebo-controlled, doubleblind trial of a complementary treatment. Scandinavian J Rheumatol1991;20:434-40. 24.Cake MA, Read RA, Guillou B, Ghosh P. Modification of articular cartilage and subchondral bone pathology in an ovine meniscectomy model of osteoarthritis by avocado and soya unsaponifiables. Osteoarth Cartil200;8:404-11.

25.Boumediene K, Felisaz N, Bogdanowicz P, Galera P, Guillou GB, Pujol JP. Avocado/soya unsaponifiables enhance the expression of transforming growth factor beta1 and beta2 in cultured articular chondrocytes. Arth Rheum1999;42:148-56.

26.Redini F, Galera P, Mauviel A, Loyau G, Pujol JP. Transforming growth factor beta stimulates collagen and glycosaminoglycan biosynthesis in cultured rabbit articular chondrocytes. FEBS Lett 1988;234(:172-6.

27.Bitto A, Burnett BP, Polito F, Marini H, Levy RM, Armbruster MA, et al. Effects of genistein aglycone in osteoporotic, ovariectomized rats: a comparison with alendronate, raloxifene and oestradiol. British J Pharmacol2008;155:896-905.

28. Shiguemoto GE, Rossi EA, Baldissera V, Gouveia CH, Valdez GM, Andrade SE. Isoflavone-supplemented soy yoghurt associated with resistive physical exercise increase bone mineral density of ovariectomized Rats. Maturitas2007;57:261-70.

29. Claassen H, Kampen WU, Kirsch T. Localization of collagens and alkaline phosphatase activity during mineralization and ossification of human first rib cartilage. Histochem Cell BIol1996;105:213-9. 


\title{
Effect of Soybean Consumption on Histometry and Histochemistry of Tibial Plateau Cartilage in Female NMRI Mice after Osteoarthritis Induction
}

\author{
Hooshmandabbasi $R^{1}$, Tootian $Z^{1^{*}}$, Morovvati $H^{1}$, Fazelipour $S^{2}$, Shojaei $B^{3}$, Kazemian $A^{1}$
}

(Received: July 8, 2017

Accepted: October 22, 2017)

\begin{abstract}
Introduction: Osteoarthritis is the most frequent knee joint disorder among old generation where it causes serious motion limitation. The objective of present study is investigating the effects of a diet containing soybean meal ingestion on relative treatment effect on knee articular cartilage in osteoarthritis induced mice.
\end{abstract}

Material \& methods: Fifty immature female NMRI mice were accidentally divided into five groups. Control group received tap water and normal diet for three months. Sham group, as induced osteoarthritis model, received Ciprofloxacin by stomach Gavage method over two weeks, $20 \mathrm{Mg} / \mathrm{kg}$ of their body weight daily. First experimental group were osteoarthritis induced over two weeks and then received null soybean meal diet by three months. The second experimental group, were fed with designed diet based on $\% 15$ soybean meal during these three months. The third experimental group was ingested with the designed diet after osteoarthritis induction. After the experimental period, values of cartilage thickness at the middle part of tibial plateau, concentration of the extracellular matrix, and concentration of alkaline phosphatase in blood serum were determined among the groups.

Findings: Comparison between the groups showed that among the groups which were fed with the diet based on $\% 15$ soybean meal either with or without osteoarthritis induction, not only the cartilage thickness at the middle part of tibial plateau but also the concentration of the glycoproteins in extracellular matrix was significantly higher than those of the groups which received the normal diet $(p<0.05)$. Furthermore, in those groups which received the designed diet either with or without osteoarthritis induction, more concentration of alkaline phosphatase in blood serum was measured. This difference, however, was not significant.

Discussion \& conclusions: Regarding the positive effects of the designed diet based on soybean meal on cartilage, addition of soybean meal in regimen in order to decrease the incidence of articular disorders can be recommended.

Keywords: Soybean meal, Osteoarthritis, Tibial plateaus cartilage, Histometry

\footnotetext{
1. Dept of Basic Sciences, Faculty of Veterinary Medicine, Tehran University, Tehran, Iran

2. Dept of Anatomy, Tehran Medical Branch, Islamic Azad University, Tehran, Iran

3. Dept of Basic Sciences, Faculty of Veterinary Medicine, Shahid Bahonar University of Kerman, Kerman, Iran
}

* Corresponding author Email: ztotian@ut.ac.ir 